\title{
First year expectations and experiences: student and teacher perspectives
}

\author{
Russell Brinkworth · Ben McCann · Carol Matthews · Karin Nordström
}

Received: 11 June 2008/Accepted: 15 November 2008/Published online: 6 December 2008

(C) The Author(s) 2008. This article is published with open access at Springerlink.com

\begin{abstract}
Transitioning from high-school to university can be difficult, and many university teachers feel students are often ill-prepared for the change. To investigate this 233 Humanities and Science students at the University of Adelaide were surveyed 6 months into their first year regarding experiences of teaching and learning at university. 189 students were also surveyed 18 months after commencement, to gain retrospective views of their transition year, as were lecturers and tutors of both groups. Results were compared to similar Orientation Week questionnaires that focused on expectations. Questions included reasons for selecting degrees, quality of teacher feedback and perceived impact of outside commitments. Even though student expectations, student experience, and teacher views differed, remarkable similarities emerged across the two degree programs (Science and Humanities). Our findings thus highlight a call for non-specialised transition programs to meet the needs of first year students and facilitate the transition from secondary to tertiary education.
\end{abstract}

Keywords Tertiary education $\cdot$ Transition $\cdot$ Mismatch $\cdot$ Feedback

All authors contributed equally to this work.

R. Brinkworth $\cdot$ K. Nordström $(\bowtie)$

School of Molecular and Biomedical Science, The University of Adelaide, Adelaide, SA 5005, Australia

e-mail: karin.nordstrom@adelaide.edu.au

R. Brinkworth

e-mail: russell.brinkworth@adelaide.edu.au

B. McCann

School of Humanities, The University of Adelaide, Adelaide, SA 5005, Australia

e-mail: benjamin.mccann@adelaide.edu.au

C. Matthews

School of History and Politics, The University of Adelaide, Adelaide, SA 5005, Australia

e-mail: carol.matthews@adelaide.edu.au 


\section{Introduction}

A 2004 survey of Australian first year students revealed that despite "[e]nhanced efforts to bridge the gap between school and university" over the previous decade, some $60 \%$ of first year students did not feel adequately prepared for university. Around a third of all commencing students even "feel ill-prepared to choose a university course on leaving school" and tend to experience an "early 'reality shock' when their first semester marks begin to come in" (Krause et al. 2005). According to another study, this "sizable minority actually find themselves in difficulties" once they begin university courses (McInnis 2001). There has been increased scholarly concern in recent times that students are inadequately prepared for entry level university courses and a perception that this has led to falling standards (Trotter and Roberts 2006). The first year experience is especially relevant as it impacts on attrition and thus on university funding, which is often tied to the number of enrolled students. Furthermore, an Australian initiative-the Learning and Teaching Performance Fund (Department of Education 2008a) - rewards universities for excellence in learning and teaching, tightly linking this to attrition rates.

The transition from high school to university is a major concern globally as demonstrated by an extensive (and rapidly expanding) literature. Much of the research in this area originates in the US where, for instance, studies have analysed the academic motivations and attrition rates of various demographic groups, such as low income students and those from ethnic minority groups (Seidman et al. 1995; Tierney 2005), showing that perceived racism had a detrimental effect on student retention (Brown et al. 2005). McCarthy and Kuh (2006) surveyed over 170,000 American high school students and reached the conclusion that a serious "mismatch" existed between the students' learning habits and the habits that would be expected of them at university. The transition from high school to university should not be considered a purely Western concern as analyses from other countries indicate. Tolstova (2006) bemoaned an apparently widening gap between Russian secondary and tertiary education and consequent drop in the standard of Russian sociology students. In Europe a study investigating the transition from high school to university found that the combination of increasing student numbers and declining secondary standards contributed to declining university standards and high failure rates during the first year (EMBO 2006).

Rausch and Hamilton (2006) highlighted the fact that of the 2.2 million students commencing at US universities, between 25 and $30 \%$ "do not return to their initial institution of choice for the second year". They noted in particular that the greatest loss occurs "during the freshman year, especially during the first semester" (Rausch and Hamilton 2006). Other studies in the US have pondered ways to enhance academic success during the first crucial year, including foregrounding the voices of minority groups in the classroom and identifying colleges with higher than average success rates (Boler et al. 2004; Kuh et al. 2005; Reason et al. 2006).

There is also a deeper problem with envisioning senior schooling as simply a means of entering university. Pressure on some school teachers to get students into university may lead to increased assistance which could set up unrealistic expectations of what students will encounter once in tertiary education. High school students enrolled in educational activities that occur outside formal schooling in Japan are thereby more likely to successfully enter university, as they achieve higher university entrance scores (Ono 2007; Stevenson and Baker 1992). However, such students are also more likely to be from high socioeconomic backgrounds, hence indicating a possible confounding 
factor. The focus on university entrance may lead to students from elite schools, where extra attention is granted, perform better at university entrance exams, but then struggle academically once in tertiary education (Birch and Miller 2007). While high rates of student admittance into university are often desirable, it is also important to retain students once enrolled. Studies from the UK, US and Australia show that retention rates, especially after first year, have been an important issue for many universities for at least the last two decades (Betts and Morrell 1999; De Rome and Lewin 1984; Johnes and McNabb 2004).

The Australian literature reflects scholars' concerns-across a broad range of disciplines-about a very real gap in students' skills between high school and university, and relates some concerted efforts to ease the transition process for first year students. For example, Macdonald (2000) noted that although moving "from secondary education to university has never been easy, in recent times the problem of the transition has become more acute". This, he argues, is due to changes in sources of university funding and has resulted in a fundamental power shift: from the university to a larger and more diverse student body upon which universities are more dependant financially than was the case 20 years ago. Indeed, as McInnis (2001) states, "first year is a priority since it is now recognised that attrition is costly for both individuals and universities". Accordingly, the literature reflects a similar shift: from analysis of this changing student body in the 1980s (Hester 1982) to suggesting ways in which the experience of transition can be eased. Ternel (2000) identified a "mismatch" between individual learning styles and university teaching methods in mechanical engineering. Furthermore, Hagan and Macdonald (2000) pointed out that the universities' expectation of students to "adjust immediately to a different style of teaching and learning was part of the problem" of transition to university.

Several strategies have been suggested for making the transition easier: Krause (2001) established that the first written assignment, particularly with effective and timely feedback upon it, can promote better integration in text-based courses. Leveson (1999) found small group work to assist accounting students. A study at La Trobe University found structural equation modelling helpful in identifying the characteristics of successful students in health sciences (McKenzie and Gow 2004) and collaboration between computing and IT proved effective at Monash University (Hagan and Macdonald 2000).

Given the transition difficulties so evident upon entry, the University of Adelaide recently conducted a survey of students commencing tertiary education (Crisp et al. 2009). In this Orientation Week survey, students from all faculties were asked what they expected in a number of areas such as workload, feedback on assignments and access to teaching staff. Interestingly, students responded that they thought studying at university would be different to high school, but consistently indicated that their expectations of access to teachers, response times for work and reviewing of drafts, was not different from high school (Crisp 2006). This suggests that while they knew there would be a change they did not really appreciate the nature of the change. The present study reports on further, and in more depth, results from two of the student groups in the original survey: those entering university to study either Humanities or Science. We have investigated the extent to which these first year students' expectations were met and considered their responses alongside their teachers' views, with particular focus on feedback.

This research is of immediate interest to those who teach first year students and those who design degree programs. In a wider context, it is of interest to universities looking to increase retention rates, to secondary educators who prepare students for admission to tertiary institutions, to employers of graduates and, of course, to students and their families. 


\section{Aims and methodology}

As related above, there is a widening gap between commencing students' expectations, and what will actually be delivered at university. Therefore the primary goal was to gain a deeper understanding of the relationship between the expectations of students entering university, the experience of first year students, and their teachers' perceptions. The secondary aim was to identify differences between Humanities and Science students and teachers.

The most effective way to achieve these objectives was to survey both students in Humanities and Science and their teachers. The benchmark was a survey of commencing students conducted by the University of Adelaide in Orientation Week of 2007 (Crisp et al. 2009). Two groups of students were requested to complete the survey again: second semester first year and second year students. Both these surveys were conducted at the same time, and thus constituted different student cohorts. They were asked to report only on their time as first year university students. This enabled a separation of the experience of the first year (first year students) and the second year students' reflections upon that experience. Additionally, teachers of first year students (Classics, French, German, History, Media, Biology, Chemistry, Geology and Physics) were asked to complete a survey that highlighted the same issue.

All questions are listed in Table 1. In questions that asked students to rank their responses to particular statements (Likert Scale) all responses were in the form: 'strongly agree', 'agree', 'neutral', 'disagree' and 'strongly disagree'. These responses were then ranked with 5 corresponding to 'strongly agree', 1 'strongly disagree' and 3 being 'neutral'. All questions also had 'not applicable' or 'other' as an option in order to ensure 'neutral' responses were not confounded by these other possibilities. We did not expand on these surveys by doing in-depth interviews, which may limit our ability to unpack student understanding of the questions asked.

One of the more problematic aspects of the survey was the question on the study time spent per week outside of class time (question 5, Table 1). In hindsight it was decided that this question was ambiguous. Given many students would be following two or more courses across different Schools and Faculties, it was unclear whether, for example, '6-10 h' (as phrased in the Orientation Week survey) meant for example in French alone, or in conjunction with, say, Medicine or Law. Therefore, further analysis of answers to this question was omitted. Likewise, the term 'ready access' had ambivalent connotations (question 7, Table 1). Did 'ready access' mean different things to a student and a teacher? Were consultation hours 'ready access' or did students expect teachers to be available at all times during the university week? Lastly, the final question was not perfectly correlated in the student and teacher surveys, as a slight change in the terminology meant the results were imbued with a distorted perspective (question 17, Table 1). This, again, highlighted the need for a future addition of qualitative data to investigate how students interpreted the questions in the surveys. Nonetheless, these admittedly minor inconsistencies allowed a reflection upon the importance of clearly worded, unambiguous questions in future pedagogical research.

Table 2 displays the similarity in answers between different groups. We calculated similarity by plotting the histograms of the responses and measuring the amount of overlap (i.e. sum of the minimum of the two values at every response level). Similarity values cannot be labelled as significant or not but give a metric to the degree of correspondence between the two groups. Importantly, this measure does not convey the level of the response, just the similarity between the respective groups. 
Table 1 Summary of survey questions used in the different groups

Question Orientation week survey Students (asked to reflect

Teachers of first year students back on their first year of university)

$1 \quad$ Are you studying full-time?

2 How many years, including the current one, have you been studying at a university?
Degree program.

Reasons for choosing program (could choose multiple reasons).

How much time per week do you expect to spend in study outside of scheduled class times?

I expect to be able to combine study with paid work.

Having 'ready' access to my lecturers and tutors outside of face-to-face teaching will be important to my success.

Feedback on my submitted work will be important to my learning.

Feedback on DRAFTS of work will be important to my learning.

It will be important for me to attend most lectures.

I have activities outside of University that might affect my ability to study.

Working with other students in class time will be important for my learning.

I anticipate that studying at university will be different to studying at high school.

What is the acceptable time for having your essays/work examined and returned to you?
Are you studying full-time?

How many years, including the current one, have you been studying at a university?

What is your main program area?

Reasons for continuing program (can select more than one):

On average how much time per week did you spend in study outside of scheduled class time?

I was, or would be, able to combine study with paid work.

I had 'ready' access to my lecturers and tutors outside of face-to-face teaching times.

Sufficient feedback was provided on my submitted work.

Feedback on my DRAFTS of work was provided.

It was important for my learning to attend most lectures.

I had outside commitments that affected my ability to study.

Working with other students in class time was important for my learning.

Studying at university was different to studying at high school.

What was the average time for essays/work to be examined and returned to you?

I learned more in classes taught by enthusiastic teachers.
What is your current position?

How many years, including the current one, have you been teaching at a university?

What is your main program area?

What do you think the main reasons students selected the program area are (you can select more than one)?

On average how much time per week do you expect students to spend in study outside of scheduled class time?

A large number of students combine study with paid work.

I provide ongoing 'ready' access for my students outside of face-to-face teaching times.

I provided sufficient feedback on students submitted work.

I provided feedback on DRAFTS of student work.

It is important for students to attend most lectures.

Students have outside commitments that affect their ability to study.

Working with other students in class is important for student learning.

The university learning environment is different to studying at high school.

I examined and returned student essays/work within:

Showing enthusiasm is an important aspect of my teaching. 
Table 1 continued

\begin{tabular}{llc}
\hline Question Orientation week survey & $\begin{array}{l}\text { Students (asked to reflect } \\
\text { back on their first year of } \\
\text { university) }\end{array}$ & Teachers of first year students \\
\hline 16 & $\begin{array}{c}\text { When in class I preferred } \\
\text { handouts/slides with } \\
\text { diagrams and pictures. }\end{array}$ & $\begin{array}{c}\text { Diagrams and pictures are an } \\
\text { important component of any } \\
\text { handouts or slides provided to } \\
\text { students. }\end{array}$ \\
$\begin{array}{ll}\text { I sought out extra } \\
\text { information about the } \\
\text { topics I found interesting } \\
\text { in class. }\end{array}$ & $\begin{array}{c}\text { Making topics interesting to } \\
\text { students is important for their } \\
\text { continues learning outside the } \\
\text { classroom. }\end{array}$ \\
\hline
\end{tabular}

Table 2 A summary of the similarity (in percentage) between the answers of different groups

\begin{tabular}{|c|c|c|c|c|c|c|c|c|c|c|}
\hline \multirow[t]{2}{*}{ Question } & \multicolumn{3}{|c|}{ Humanities } & \multicolumn{3}{|l|}{ Science } & \multicolumn{4}{|c|}{ Humanities vs. Science } \\
\hline & $\begin{array}{l}0 \text {-Week } \\
\text { vs. year } 1\end{array}$ & $\begin{array}{l}0 \text {-Week } \\
\text { vs. year } 2\end{array}$ & $\begin{array}{l}\text { Year } 1 \\
\text { vs. } 2\end{array}$ & $\begin{array}{l}\text { 0-Week } \\
\text { vs. year } 1\end{array}$ & $\begin{array}{l}0 \text {-Week } \\
\text { vs. year } 2\end{array}$ & $\begin{array}{l}\text { Year } 1 \\
\text { vs. } 2\end{array}$ & $\begin{array}{l}0- \\
\text { Week }\end{array}$ & $\begin{array}{l}\text { Year } \\
1\end{array}$ & $\begin{array}{l}\text { Year } \\
2\end{array}$ & Teachers \\
\hline 4 & 76 & 88 & 88 & 83 & 79 & 91 & 88 & 84 & 81 & 82 \\
\hline 5 & 61 & 78 & 86 & 75 & 62 & 85 & 91 & 90 & 86 & 54 \\
\hline 6 & 87 & 90 & 94 & 82 & 85 & 90 & 96 & 86 & 89 & 81 \\
\hline 7 & 73 & 85 & 85 & 61 & 68 & 89 & 90 & 89 & 81 & 53 \\
\hline 8 & 41 & 46 & 87 & 36 & 37 & 85 & 97 & 71 & 74 & 5 \\
\hline 9 & 26 & 27 & 61 & 16 & 35 & 71 & 87 & 80 & 69 & 38 \\
\hline 10 & 69 & 81 & 87 & 86 & 70 & 81 & 97 & 79 & 85 & 81 \\
\hline 11 & 82 & 77 & 87 & 83 & 75 & 83 & 93 & 95 & 85 & 73 \\
\hline 12 & 74 & 87 & 83 & 77 & 76 & 94 & 97 & 93 & 88 & 81 \\
\hline 13 & 87 & 80 & 91 & 87 & 86 & 97 & 95 & 93 & 92 & 55 \\
\hline 14 & 88 & 71 & 74 & 57 & 69 & 85 & 95 & 67 & 88 & 74 \\
\hline 15 & & & 88 & & & 88 & & 92 & 84 & 82 \\
\hline 16 & & & 81 & & & 89 & & 74 & 79 & 30 \\
\hline 17 & & & 92 & & & 82 & & 87 & 75 & 84 \\
\hline
\end{tabular}

When determining significant differences between responses two areas of interest were used: Humanities versus Science (i.e. Orientation week Humanities students vs. Orientation week Science students, first year Humanities students vs. first year Science students, second year Humanities students vs. second year Science students, Humanities teachers vs. Science teachers) and teachers versus student groups (i.e. Orientation week Humanities students vs. Humanities teachers, first year Humanities students vs. Humanities teachers, second year Humanities students vs. Humanities teachers, and then the same for the Science Faculty). To calculate where these significant differences lay $95 \%$ confidence intervals were constructed (mean $\pm 1.96 *$ standard error). Significant differences were allocated to $P<0.05$.

Where numerical results on 'agreement' are quoted in the text (and in Table 4) they are in the form of the percentage of responses that were either 4 or 5, i.e. those who 'agreed' or 'strongly agreed' with the statement. Agreement values cannot be labelled as significant or not. 


\section{Results}

\section{General overview}

While commencing students have been surveyed for previous studies [for example, the Australian Department of Education, Science and Training conducts an annual nation-wide survey (Department of Education 2008b)], the present study appears to be the first to both conduct follow-up research and to do so across two major faculties: Humanities and Science (with little prior research having been conducted in the Humanities). To our knowledge, this is also the first attempt to seek and relate both student and teacher perspectives on the first year experience and to do so longitudinally.

We received completed surveys (17 questions, Table 1) from:

- 111 first year Humanities (French and History) students

- 122 first year Science (Biology and Geology) students

- 86 second year Humanities (Classics, French, German, History, Media and Politics) students

- 103 second year Science (Biology and Physics) students

- 11 teachers of first year Humanities (Classics, French, German, History and Media)

- 17 teachers of first year Science (Biology, Chemistry, Geology and Physics)

The surveys were distributed online to students enrolled in the second semester of 2007, and lectures were also targeted with hard copies. The completed surveys were compared with the responses retrieved from the 2007 Orientation Week surveys of 185 Humanities and 456 Science students (Crisp et al. 2009). We did not ask any demographical questions, and therefore do not have data on age, sex or international status. However, we did find out that $95 \%$ of the surveyed students were enrolled full time at the University of Adelaide. We also know from Nationwide surveys that $68 \%$ of students enrolled at the University of Adelaide are domestic, and that $49 \%$ are male (Department of Education 2008b). We can assume that the cohorts we targeted did not deviate too much from these numbers.

The mean responses are shown in Table 3. Unsurprisingly, over $90 \%$ of commencing students expected university to be different to high school (Crisp et al. 2009). Almost all teachers and continuing students later agreed or strongly agreed with the notion that "Studying at university was different to studying at high school" (question 13, Table 4). However, students' expectations of university life compared with high school proved unrealistic when asked more specific questions on workload, feedback on work, and access to teachers (Crisp et al. 2009). For example, we identified large differences in expectations and later experience of feedback on assignments and drafts. There is also an expectation of 'ready' access to teachers in Science (89\% student agreement in Orientation Week), which was not met (first year 50\% agreement, second year 57\%). The same trend was found in the Humanities student population (question 7, Table 4). Interestingly, the Science teachers actually felt that they were accessible (94\% agreement), whereas those from Humanities indicated that their availability was not as high (64\% agreement).

Science and Humanities students have similar experience of their first year at university

In general we found very few differences between Humanities and Science students with no significant differences to any of the questions during Orientation Week (see Tables 2, 3). For example, both first year groups thought it was important to attend most lectures (first year Humanities agreement $79 \%$ vs. Science $90 \%$ agreement, with $79 \%$ similarity between 
Table 3 Average responses to selected questions using the Likert scale, [from 1 (strongly disagree) to 5 (strongly agree), with 3 as neutral]

\begin{tabular}{|c|c|c|c|c|c|c|c|c|}
\hline \multirow[t]{2}{*}{ Question } & \multicolumn{4}{|c|}{ Humanities } & \multicolumn{4}{|l|}{ Science } \\
\hline & 0-Week & Year 1 & Year 2 & Teacher & 0-Week & Year 1 & Year 2 & Teacher \\
\hline 6 & 3.97 & $3.88 *$ & 3.93 & 4.45 & $3.87 * *$ & $3.47 * * *$ & $3.75 * *$ & 4.82 \\
\hline 7 & 4.21 & 3.63 & 3.86 & $3.73^{*}$ & 4.33 & $3.40 * *$ & $3.62 * *$ & $4.63 *$ \\
\hline 8 & $4.66^{* *}$ & $3.52 * * *$ & $3.81 * * *$ & $5.00 *$ & $4.65 * *$ & $2.96^{*}$ & $3.15^{*}$ & $3.47 *$ \\
\hline 9 & $4.59 * *$ & $2.75 * *$ & $2.63 * *$ & $1.36^{*}$ & $4.48 * *$ & 2.56 & 2.76 & $2.49 *$ \\
\hline 10 & 4.59 & $3.98 * * *$ & 4.19 & 4.64 & 4.63 & $4.34 * * *$ & $4.19 * *$ & 4.82 \\
\hline 11 & $3.06^{* *}$ & $3.28 * *$ & $3.46^{* *}$ & 4.27 & $3.10^{* *}$ & $3.12^{* *}$ & $3.50 * *$ & 4.53 \\
\hline 12 & $3.96 * *$ & $3.43 * *$ & $3.80 * *$ & 4.64 & 4.04 & $3.52 * *$ & $3.58 * *$ & 4.41 \\
\hline 13 & 4.44 & 4.56 & 4.52 & $4.27 *$ & $4.51^{* *}$ & $4.60 * *$ & $4.67 * *$ & $5.00 *$ \\
\hline 15 & & $4.59 * *$ & $4.73 * *$ & 5.00 & & 4.68 & $4.49 * *$ & 4.88 \\
\hline 16 & & $3.91 *$ & 3.83 & $3.64 *$ & & $4.38 * * *$ & $4.17 * *$ & $4.88 *$ \\
\hline 17 & & $3.75 * *$ & $3.87 * * *$ & 4.73 & & $3.50 * *$ & $3.43 * * *$ & 4.71 \\
\hline
\end{tabular}

* Significant differences $(P<0.05)$ between science and humanities faculties

** Significant differences between teachers and student groups within a faculty

Table 4 Percent of respondents agreeing or strongly agreeing with the question asked

\begin{tabular}{|c|c|c|c|c|c|c|c|c|}
\hline \multirow[t]{2}{*}{ Question } & \multicolumn{4}{|c|}{ Humanities } & \multicolumn{4}{|l|}{ Science } \\
\hline & 0-Week & Year 1 & Year 2 & Teacher & 0-Week & Year 1 & Year 2 & Teacher \\
\hline 6 & 74.6 & 74.8 & 76.7 & 81.8 & 70.4 & 60.7 & 69.6 & 100 \\
\hline 7 & 88.1 & 61.3 & 73.3 & 63.6 & 88.8 & 50 & 57.3 & 94.1 \\
\hline 8 & 97.3 & 65.8 & 74.4 & 100 & 97.1 & 36.9 & 48.0 & 58.8 \\
\hline 9 & 93.5 & 19.8 & 20.9 & 0 & 90.8 & 6.56 & 26.2 & 21.6 \\
\hline 10 & 96.2 & 79.3 & 84.9 & 100 & 96.5 & 90.2 & 87.2 & 100 \\
\hline 11 & 35.1 & 49.6 & 53.5 & 72.7 & 34.7 & 44.3 & 57.6 & 94.1 \\
\hline 12 & 80.5 & 54.0 & 69.8 & 100 & 82.9 & 59.8 & 59.0 & 82.4 \\
\hline 13 & 93.5 & 94.6 & 89.5 & 72.7 & 94.3 & 95.1 & 95.2 & 100 \\
\hline 15 & & 94.6 & 97.7 & 100 & & 97.5 & 90.3 & 94.1 \\
\hline 16 & & 67.6 & 58.1 & 45.5 & & 89.3 & 78.6 & 100 \\
\hline 17 & & 70.3 & 75.6 & 100 & & 58.2 & 50.5 & 94.1 \\
\hline
\end{tabular}

responses). Students believed that working with other students was important for their learning (second year Humanities agreement $70 \%$ vs. Science 60\%, 88\% similarity between responses) and both first year groups indicated that they learnt more from enthusiastic teachers (Humanities 95\% agreement vs. Science 98\%, 92\% similarity between responses).

Students from both Humanities and Science preferred pictures and diagrams in slides and handouts (Fig. 1). However, there was a large difference between the answers from Humanities and Science teachers (Fig. 1). When asked if they were more likely to seek out extra information about interesting topics, $70-75 \%$ of Humanities students agreed while only $50-60 \%$ of Science students agreed (see Tables 3, 4). However, their teachers 


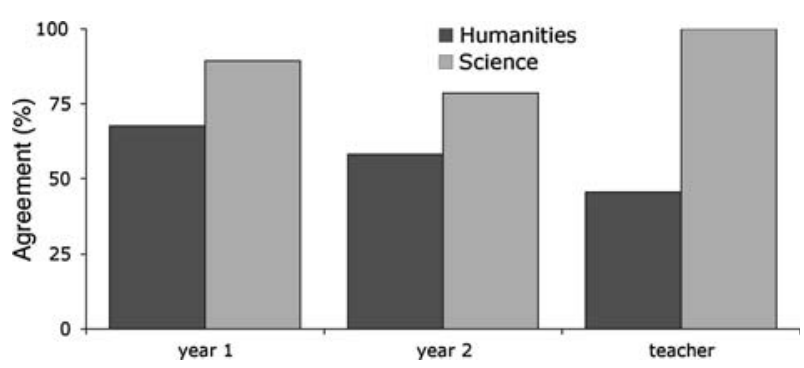

Fig. 1 Diagrams and pictures in handouts and slides are important for learning. The $y$-axis represents percent of respondents agreeing or strongly agreeing with the notion that diagrams and pictures are an important of any handouts and/or slides (question 16, Table 1). Science teachers apparently had a stronger tendency to utilise diagrams and figures than their Humanities counterparts

believed that making topics interesting is important for their continued learning outside the classroom (Humanities 100\% vs. Science 94\% agreement).

We found that students initially chose, and then stayed within, their programs for very similar reasons: interest was by far the largest factor in selecting and continuing a degree program (Fig. 2; Table 2). Developing talent and creativity was just as important as job prospects for commencing students in Humanities (Crisp et al. 2009). This indicates that the key differences routinely cited between Humanities and Science (i.e. the former is chosen because of creativity, the latter because of job prospects) actually remain slight at the high school to university boundary. However, job prospects later went up as a reason for continuing the program in Science (Fig. 2b).

\section{Outside commitments}

The teachers of first year students assumed that they did have outside commitments that would affect their ability to study but this was not borne out by the student responses (Fig. 3). The average student response was 'neutral' (i.e. the students indicated neither way whether they would be affected by outside commitments), whereas the teacher results were much higher. This mismatch between teacher and student experiences has potentially awkward ramifications as it indicates that the thorny issue of outside commitments (whether paid or voluntary work, creative arts or sports commitments, etc.) is not as critical to students as teachers might think. The data suggests that students are perhaps not as overloaded, or at least they do not perceive they are, as anecdotal evidence might suggest. A similar question asked whether they were able to (or would be able to) combine studying with paid work. $75 \%$ of Humanities and $65 \%$ of Science students (question 6, Table 4) agreed or strongly agreed that this was possible, while most teachers assumed that a large number of students were combining studies with work (Humanities $82 \%$ vs. Science $100 \%$ agreement).

The importance of feedback

Other instances of clear mismatches between expectations and experience were found. Firstly, it was noticed in the question of whether the students believed feedback on drafts would be important for their learning and then whether they actually received such feedback (see shift from Orientation Week to year 1 and 2 in Fig. 4). The answers to this 

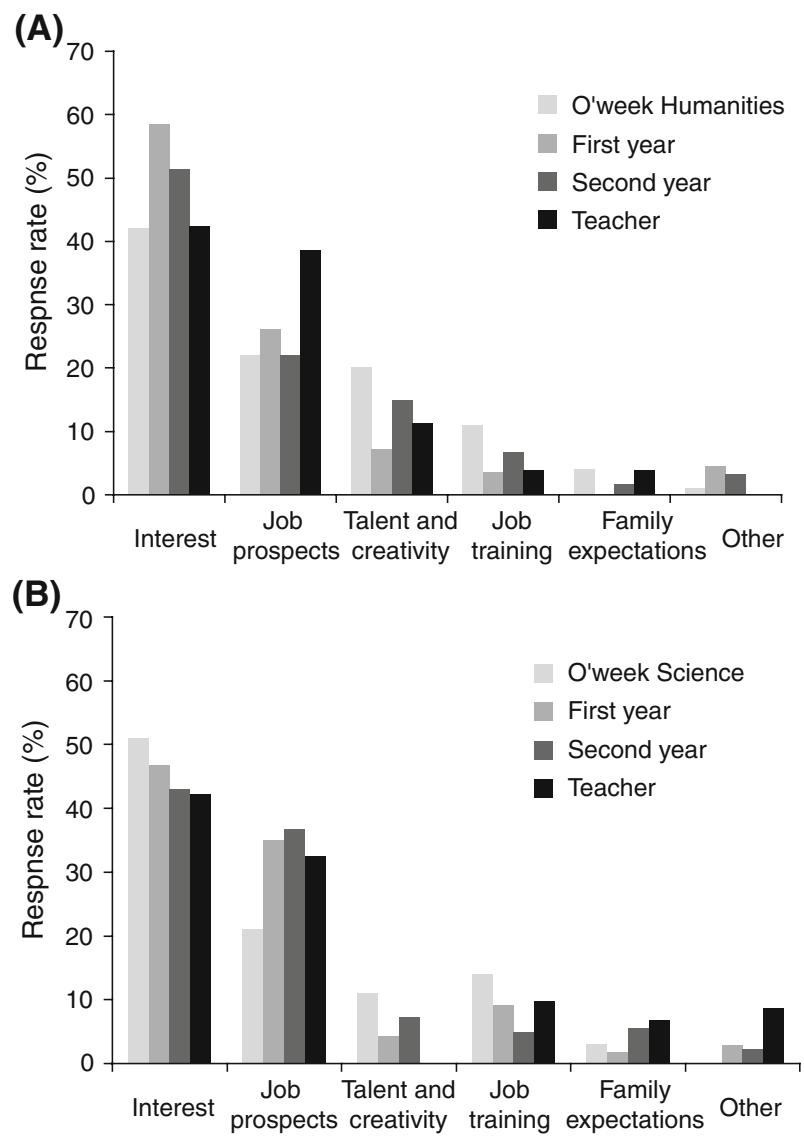

Fig. 2 Reason for choosing/continuing program. a. The students were asked why they chose their particular program in Orientation week. We then asked the students in year 1 and 2 why they continued in their chosen program, and we also asked their teachers why they thought the students chose their program. (question 4, Table 4). The $y$-axis represents percent of answers; more than one answer could be chosen. $\mathbf{b}$. The same kind of data for the Science students and teachers. Despite the difference in the chosen degrees there were clear similarities between Science and Humanities

question (question 9, Table 2) show less than 20\% similarity between Orientation week and year 1 and 2 in both Humanities and Science. It also shows that commencing students had very strong $(>90 \%)$ expectations of receiving such feedback before starting university (Crisp et al. 2009). Thus, students reported that their expectations were not met and their teachers agreed that they did not generally provide feedback on drafts $(0 \%$ agreement in Humanities and $22 \%$ in Science, Fig. 4). However, note the difference between the two Science student groups. Only $7 \%$ of students in their first year agreed they received feedback on drafts while $26 \%$ of science students reflecting upon their first year said they received feedback on drafts. This difference indicates that either the students did not notice the feedback they were getting at the time, or that they were more generous, in hindsight, as to their definition of feedback. This difference was not seen in the Humanities with $20 \%$ of first year and $21 \%$ of second year students stating they got feedback on drafts. However, this in itself is interesting as none of the Humanities teachers said they actually provided such feedback (Fig. 4). 


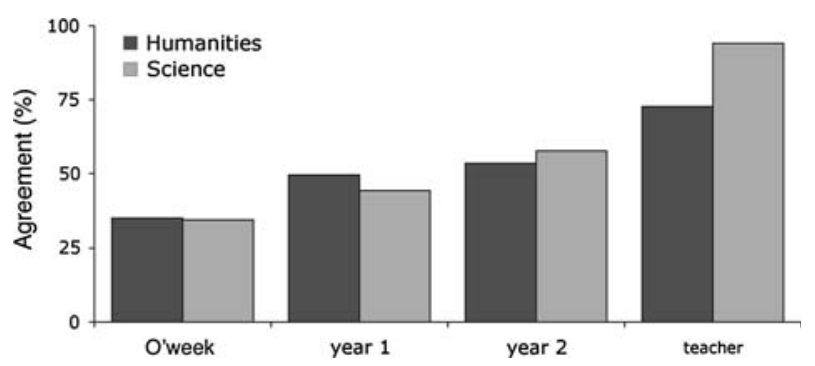

Fig. 3 Outside commitments affected ability to study. The students were originally (Orientation week) asked if they had activities outside university that might affect their ability to study. In our follow-up they were asked if they did indeed have outside commitments in year 1, and the teachers were asked if they believed that outside commitments affected the student's ability to study (question 11, Table 1). The answers are colour-coded for students from Humanities (dark grey) and Sciences (light grey), with the $y$-axis representing percent of respondents agreeing or strongly agreeing with the question asked. The teachers clearly thought that outside commitments had a larger effect on learning than the students themselves did

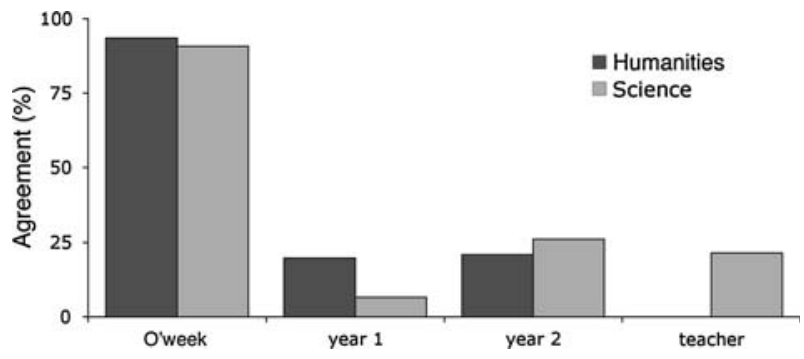

Fig. 4 Feedback on drafts was provided. While Orientation week students believed that feedback on drafts would be important for their learning, this expectation was clearly not met, nor did the teachers expect to give it (question 9, Table 1). The answers are colour-coded for students from Humanities (dark grey) and Sciences (light grey), with the $y$-axis representing percent of respondents agreeing or strongly agreeing with the question asked

A further discrepancy was found in the issue of feedback on submitted work (not drafts). Students across both disciplines said that they expected feedback to be important for their learning, but it seemed this objective was not being met as highly as they would have liked (question 8, Table 4). This is evidenced by a clear mismatch between the Orientation week students' expectation of feedback on submitted work ( $97 \%$ agreement from both Humanities and Science students) and their later experience (down to 66\% agreement in first year Humanities and 37\% in Science). While Humanities teachers perceived that they provided sufficient feedback (100\% agreement), at a level similar to Orientation Week expectations, Science teachers agreed more weakly with this notion (59\% agreement). Humanities teachers may think that they are providing sufficient feedback, but this is not necessarily the students' perception. In contrast, many Science teachers are aware they do not provide sufficient feedback.

Another example related to return times for submitted work. As can be seen in Fig. 5, $90 \%$ of commencing students believed that acceptable return time for submitted work was less than 3 weeks. This is clearly an unrealistic expectation when, in fact, $30 \%$ of second year students said that it actually took 3-6 weeks for work to be returned to them in first year. Astonishingly, it sometimes took even more than 6 weeks for work to be returned in the Science faculty (Fig. 5b). This is clearly a poor outcome if a goal of early assignments 

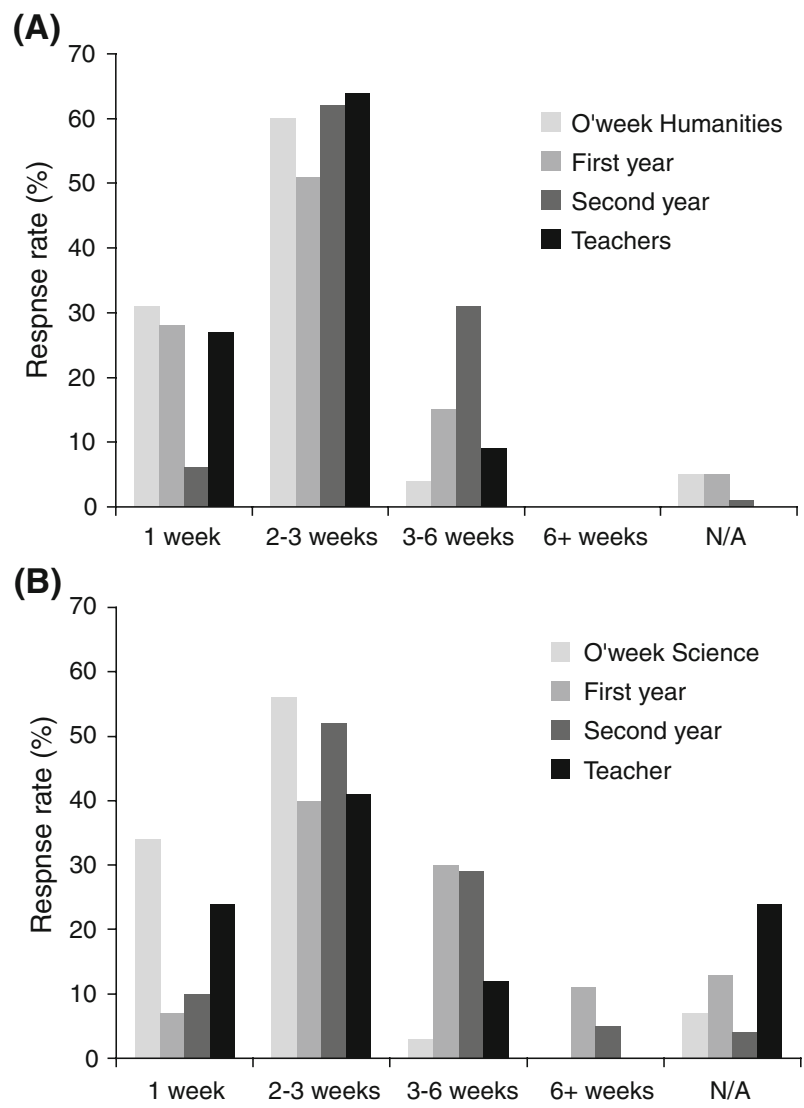

Fig. 5 Expected return times for submitted work. a. Humanities students were asked what return time they expected for submitted work before commencing university. We then asked the students in year 1 and 2 how long it actually took for work to be returned to them, and we also asked their teachers how long they took to return work (question 14, Table 1). The $y$-axis represents percent of answers. b. The same kind of data for the Science students and teachers. Despite differences in degrees there are clear similarities between Science and Humanities

is to prepare students for future learning towards other assignments or exams (Harvey and Knight 1996; Higgins et al. 2002; Horsburgh 1999).

\section{Discussion}

Our survey of the first year experience confirms that transitioning to university can be an eye-opener. The Orientation week survey found that students know university is going to be different to high school but they do not expect a difference (Crisp et al. 2009). Furthermore, student responses in the study presented here indicates that a successful transition is not solely due to academic ability, but depends also on an ability to make a rapid adjustment to a learning environment that requires greater autonomy and individual responsibility than students expect upon commencement. 
Corroboration of Ternel's (2000) 'mismatch' between learning styles and teaching methods became evident after analysing our data. For example, over $90 \%$ of Humanities and Science students responded that studying at university would be different from studying at high school, yet a high percentage still expected quick feedback on returned work (Fig. 5), ready access to teachers, and feedback on drafts (Fig. 4) as crucial to the university experience: a view not corroborated by their teachers' self-reporting of their practice (Tables 2,3). It is this disjunction that goes a long way to prove that the transition process between secondary and tertiary education is acute and remains fraught with inconsistencies.

Issues relating to feedback emerged as a consistent point of discrepancy between student expectations, and student and teacher experience. Feedback was a particularly important focus for our study because the effective and regular delivery of feedback remains a fundamental mechanism for making new university students feel supported, accustomed to and comfortable within the university environment (Long et al. 2006). Despite the fact that many studies have shown feedback to be an essential part of learning, as it specifically relates on performance and thereby enables improvement and higher-order learning (Sadler 1998), our study shows that the expectations of commencing students are clearly not met (e.g. Figs. 4, 5). It has been shown that feedback is one of the most effective means of promoting transformative learning (Harvey and Knight 1996), that feedback on drafts is valuable (Higgins et al. 2002) and that students themselves find feedback extremely important for their learning (Horsburgh 1999). For feedback to be efficient it should be delivered promptly after assessment (Rust 2002) rather than up to 6 weeks after submission, as was sometimes the case as found in our study (Fig. 5). In fact, unless feedback is timely, students are quite unlikely to review the assignment to find out where they went wrong (Mackenzie 1976). University teachers face the problem of increasing workloads with increasing student numbers, and it is therefore not surprising to see a discrepancy between feedback wanted and feedback given, and the timeframe in which it is returned. One solution to this could be to aid the students in becoming better internal generators of feedback, thus easing the workload of their teachers (Nicol and Macfarlane-Dick, 2006).

The issues of outside commitments and activities, such as paid work, emerged as a discrepancy between student and teacher experience. It appears that students and their teachers have very different ideas about students' outside commitments and the impact they might have upon students' study loads (see questions 6 and 11, Tables 3, 4). Such a difference raises questions worthy of further study about both teachers and students. Why do teachers assume that their students' ability to study is affected by outside commitments? Is there a perceived drop in grades, which they attribute to students' spending insufficient time on their studies? If so, how much time per week do they feel is necessary for students to absorb subject matter and complete assignments adequately? Or, do they assume that the allocation of more time would result in better academic results overall? What of the students' responses? Do today's undergraduates see study simply as one facet of their lives and are they able to juggle commitments successfully? If so, it may have a positive rather than negative impact on students. A recent study of students' extra-curricular activities in the UK found that this may indeed be the case. Not only did students in that study value outsides activities in terms of personal development, but students who tended to be involved in such activities were found to have made the transition from university to the workplace more easily (Tchibozo 2007).

On the other hand, are academic results really as unaffected by outside commitments as this sample of students' responses would suggest? Perhaps the sample group are either not 
as aware of the impact paid work has on their studies as are their teachers, or they were unwilling to admit being overloaded. One group, for example, for whom outside commitments are proving a barrier to study are women who care for children (Lister 2003). These are significant questions because universities are adjusting to, and seeking to retain, a larger and more diverse student body for whom university study is something that must (whether teachers or students like it or not) fit into a life which includes one or more other priorities. This mismatch is something, then, that universities must take into account: now and into the future.

The implications of our research for student retention are important. There is a tendency to attribute lower levels of university completion and higher levels of withdrawal in first year student groups to a lack of 'academic preparedness' (Thomas 2003). If students feel that they are prepared for study at tertiary level, and, crucially, the institution provides academic support if and when required, then a greater sense of academic and social inclusiveness can be initiated. Moreover, successfully reducing early attrition rates and stabilizing enrolments permits a more efficient allocation of resources as well as providing improved return on the institution's investment (Martinez 2003). Our results highlight that flexible teaching and learning strategies are vital in promoting a climate of inclusiveness, and that the gaps between expectation and experience on issues such as feedback and teacher availability need to be identified and addressed more quickly. This in turn will have a positive effect on student retention, not least because many first-year students who identify academic reasons for their discontinuation in tertiary education largely fall into two groups: those faced with poor quality teaching and/or those with inadequate or poor interaction with teaching staff (Long et al. 2006).

If, as Reason et al. (2006) agree, the first year at university for any student, regardless of program of study, is "critical not only for how much students learn but also for laying the foundation on which their subsequent academic success and persistence rest", then mechanisms need to be put into place that enable them to bridge the transition from high school to university and facilitate a successful integration into the changed demands of tertiary education. Thus, a broader question remains open and needs to be addressed: how can the expectations of first year students be better balanced and integrated?

Possible solutions include the kind being increasingly introduced in universities in the US, in which online 'study skills' check lists are collaboratively developed by science high school and university teachers and made available to first year students (University of Alberta 2007; University of Wisconsin 2002). Elsewhere, researchers at Edith Cowan University piloted an on-line transition project entitled 'Click Around ECU' that sought to empower high school pupils to decide for themselves what school leavers want to know about university life through the production of web based multimedia presentations (Hunt et al. 2002). Pargetter et al. (1998) have suggested implementing 'transition charters' in universities at which academic orientation programs are specifically designed to identify mismatches between course expectations and course experiences at the outset.

We would also add that first year teachers and university policy makers need to reflect on the data in a constructive way to conceptualise possible changes in teaching practice, and that universities will need to seek out ways to incorporate greater intellectual and social integration among the student population. Rather than orientation to university life revolving around "a didactic process in which those in-the-know teach the uninitiated" (Hunt et al. 2002), we would argue that more proactive and earlier interventionist strategies are required. By showing the disjunction between student expectations and their experiences our findings highlight a call for non-specialised transition programs to meet the needs of first year students, help inform them of the realities of university life and hence 
facilitate the transition from secondary to tertiary education. Such courses would identify and address current social, cultural and academic transition issues, and, given the universality of these issues, would be customisable and deliverable to non-subject specific academic cohorts.

This project has made some demonstrably important steps in reflecting upon the first year experience as well as focussing on some of the revealing discrepancies between expectation and experience. More work is now called for to investigate and evaluate more widely the transition process from secondary to tertiary education by expanding into other faculties, institutions and even the secondary school sector. Finally, there is a need to design and trial transition programs using the knowledge gained from such studies to better address this increasingly widespread issue by.

Acknowledgments The authors would like to thank Geoffrey Crisp, Edward Palmer and colleagues for granting access to unpublished work and encouraging us to proceed with this follow-on study. We would also like to thank Velta Vingelis, Judith Pollard and Karin Barovich for their assistance in collecting teacher data. We also thank two anonymous reviewers whose comments substantially improved the paper, and we especially thank John Willison for his ongoing support and constructive comments on early versions of the manuscript.

Open Access This article is distributed under the terms of the Creative Commons Attribution Noncommercial License which permits any noncommercial use, distribution, and reproduction in any medium, provided the original author(s) and source are credited.

\section{References}

Betts, J. R., \& Morrell, D. (1999). The determinants of undergraduate grade point average: The relative importance of family background, high school resources, and peer group effects. The Journal of Human Resources, 34, 268-293. doi:10.2307/146346.

Birch, E. R., \& Miller, P. W. (2007). The influence of type of high school attended on university performance. Australian Economic Papers, 46, 1-17. doi:10.1111/j.1467-8454.2007.00302.x.

Boler, M., Kincheloe, J. L., \& Steinberg, S. R. (2004). Democratic dialogue in education: Troubling speech, disturbing silence. Lang: Peter Publishing.

Brown, R., Morning, C., \& Watkins, C. (2005). Influence of African American engineering student perceptions of campus climate on graduation rates. Journal of Engineering Education, 94, 263-271.

Crisp, G. (2006). First year expectations: A report on the outcomes of a university wide survey. In ERGA Conference. Building higher education that works: Methods and results, Adelaide.

Crisp, G., Palmer, E., Turnbull, D., Nettelbeck, T., Ward, L., LeCouteur, A., Sarria, A., Strelan, P., \& Schneider, L. (2009). First year student expectations: Results from a university wide survey. Journal of University Teaching and Learning Practice. (in press).

De Rome, E., \& Lewin, T. (1984). Predicting persistence at university from information obtained at intake. Higher Education, 13, 49-66. doi:10.1007/BF00136530.

Department of Education, Employment and Workplace Relations. (2008a). An evaluation of the learning and teaching performance fund. Department of Education, Employment and Workplace Relations. http:// www.dest.gov.au/sectors/higher_education/policy_issues_reviews/key_issues/learning_teaching/ltpf/.

Department of Education, Employment and Workplace Relations. (2008b). Students 2007: selected higher education statistics. http://www.dest.gov.au/sectors/higher_education/publications_resources/profiles/ Students_2007_full_year_htm.

EMBO. (2006). From School to University - a report on the transition from secondary school biology education to university in Europe. http://www.embo.org/scisoc/report.pdf Accessed 30 Oct 2008.

Hagan, D., \& Macdonald, I. (2000). A collaborative project to improve teaching and learning in first year programming. Australasian Journal of Engineering Education, 9, 65-76.

Harvey, L., \& Knight, P. T. (1996). Transforming higher education. Buckingham: Open University Press. Hester, D. (1982). Student selection for tertiary education. Australia: Advisory Centre Occasional Papers in University Education, University of Adelaide. 
Higgins, R., Hartley, P., \& Skelton, A. (2002). The conscientious consumer: Reconsidering the role of assessment feedback in student learning. Studies in Higher Education, 27, 53-64. doi:10.1080/0307 5070120099368.

Horsburgh, M. (1999). Quality monitoring in Higher Education: The impact on student learning. Quality in Higher Education, 5, 9-25. doi:10.1080/1353832990050102.

Hunt, L., Kershaw, L., \& Seddon, J. (2002). Authentic transitions: The click around ECU on-line transition to university program. Higher Education Research \& Development, 25, 338-353.

Johnes, G., \& McNabb, R. (2004). Never give up on the good times: Student attrition in the UK. Oxford Bulletin of Economics and Statistics, 66, 23-47. doi:10.1111/j.1468-0084.2004.00068.x.

Krause, K.-L. (2001). The university essay writing experience: A pathway for academic integration during transition. Higher Education Research \& Development, 20, 147-168.

Krause, K.-L., Hartley, R., James, R., \& McInnis, C. (2005). The first year experience in Australian universities: Findings from a decade of national studies (p. 115). Australia: Department of Education, Science and Training.

Kuh, G. D., Kinzie, J., Schuh, J. H., \& Whitt, E. J. (2005). Student success in college: Creating conditions that matter. San Francisco: Jossey-Bass Higher \& Adult Education.

Leveson, L. (1999). Small group work in accounting education: An evaluation of a programme for first-year students. Higher Education Research \& Development, 18, 361-377. doi:10.1080/0729436990180306.

Lister, P. G. (2003). It's like you can't be a whole person, a mother who studies. Lifelong learning: Mature women students with caring commitments in social work education. Social Work Education, 22, 125138. doi:10.1080/0261547022000058189.

Long, M., Ferrier, F., \& Heagney, M. (2006). Stay, play or give it away? Students continuing, changing or leaving university study in their first year. Department Education, Employment and Workplace Relations. Available at http://www.dest.gov.au/NR/rdonlyres/678FF919-3AD5-46C7-9F577398416 98A85/.

Macdonald, I. (2000). What do we mean by transition, and what is the problem? Australasian Journal of Engineering Education, 9, 7-20.

Mackenzie, K. (1976). Student reactions to tutor comments on the tutor-marked assignment. Teaching at a Distance, 5, 53-58.

Martinez, M. (2003). High attrition rates in e-Learning: Challenges, predictors, and solutions. The e-Learning Developers Journal, 14, 1-9.

McCarthy, M., \& Kuh, G. D. (2006). Are students ready for college? What student engagement data say. Phi Delta Kappan, 87, 664-669.

McInnis, C. (2001). Researching the first year experience: Where to from here? Higher Education Research \& Development, 20, 105-114.

McKenzie, K., \& Gow, K. M. (2004). Exploring the first year academic achievement of school leavers and mature-age students through structural equation modelling. Learning and Individual Differences, 14, 107-123. doi:10.1016/j.lindif.2003.10.002.

Nicol, D. J., \& Macfarlane-Dick, D. (2006). Formative assessment and self-regulated learning: A model and seven principles of good feedback practice. Studies in Higher Education, 31, 199-218. doi:10.1080/ 03075070600572090 .

Ono, H. (2007). Does examination hell pay off? A cost-benefit analysis of "ronin" and college education in Japan. Economics of Education Review, 26, 271-284. doi:10.1016/j.econedurev.2006.01.002.

Pargetter, R., McInnis, C., James, R., Evans, M., Peel, M., \& Dobson, I. (1998). Transition from secondary to tertiary: A performance study. Canberra: Department of Education, Training and Youth Affairs.

Rausch, J. L., \& Hamilton, M. W. (2006). Goals and distractions: Explanations of early attrition from traditional university freshmen. The Qualitative Report, 11, 317-334.

Reason, R. D., Terenzini, P. T., \& Domingo, R. J. (2006). First things first: Developing academic competence in the first year of college. Research in Higher Education, 47, 149-175. doi:10.1007/s11162005-8884-4.

Rust, C. (2002). The impact of assessment on student learning: How can the research literature practically help to inform the development of departmental assessment strategies and learner-centred assessment practices. Active Learning in Higher Education, 3, 145-158. doi:10.1177/1469787402003002004.

Sadler, D. R. (1998). Formative assessment: Revisiting the territory. Assessment in education: Principles. Policy \& Practice, 5, 77-85.

Seidman, E., Allen, L., Aber, J. L., Mitchell, C., Feinman, J., Yoshikawa, H., et al. (1995). Development and validation of adolescent-perceived microsystem scales: social support, daily hassles, and involvement. American Journal of Community Psychology, 23, 355-388. doi:10.1007/BF02506949.

Stevenson, D.-L., \& Baker, D. P. (1992). Shadow education and allocation in formal schooling: Transition to University in Japan. American Journal of Sociology, 97, 1639-1657. doi:10.1086/229942. 
Tchibozo, G. (2007). Extra-curricular activity and the transition from higher education to work: A survey of graduates in the United Kingdom. Higher Education Quarterly, 61, 37-56. doi:10.1111/j.14682273.2006.00337.x.

Ternel, I. (2000). Low achievement and the mismatch between personal and university learning styles in mechanical engineering students. Australasian Journal of Engineering Education, 9, 93-104.

Thomas, L. (2003). Student retention in higher education: The role of institutional habitus. Journal of Education Policy, 17, 423-442. doi:10.1080/02680930210140257.

Tierney, W. G. (2005). The changing landscape of higher education: The future of college admission. Arlington: National Association for College Admission Counselling.

Tolstova, I. N. (2006). Between school and college: Is the gap getting wider? Thoughts of a sociology instructor. Russian Education \& Society, 48, 7-26. doi:10.2753/RES1060-9393480601.

Trotter, E., \& Roberts, C. A. (2006). Enhancing the early student experience. Higher Education Research \& Development, 25, 371-386. doi:10.1080/07294360600947368.

University of Alberta. (2007). T2U: Transition to University. www.ualberta.ca/ uts/STLHE/_pdf/ T2U\%20Transition\%20to\%20University.pdf. Accessed 1 May 2008.

University of Wisconsin. (2002). Study skills—culture shock: Transitions between high school and college. http://bioweb.uwlax.edu/website/website.htm. Accessed 1 May 2008. 